\title{
Who is the African Farmer? The Importance of Actor Representations in the Debate About Biotechnology Crops in Africa
}

\author{
Koen Beumer ${ }^{1}$. Jac. A. A. Swart ${ }^{2}$
}

Accepted: 23 January 2021 / Published online: 9 February 2021

(c) The Author(s) 2021

\begin{abstract}
The discussion about the impact of agricultural biotechnology on Africa is deeply divided and contains widely diverging claims about the impact of biotechnology on African farmers. Building upon literature on the 'good farmer' that highlights that farmers identities are an important factor in explaining the success or failure of agricultural change, we argue that the identity of the farmer is an undervalued yet crucial aspect for understanding the debate about the impact of agricultural biotechnology on African farmers. In this article we therefore investigate what farmers' identities are implicated in the arguments about the impact of biotechnology on African farmers. We aim to identify the main fault lines in different accounts of the African biotechnology farmer by analysing the identities ascribed to them in two prominent cases of controversy: the debates at the 2002 World Summit on Sustainable Development in Johannesburg and the discussion about the impact of biotechnology on smallholder farmers in the Makhathini flats in KwaZulu Natal, South Africa. Our findings demonstrate that arguments about biotechnology are informed by diverging conceptions of who the African farmer is, what is important for the African farmer, and what role the African farmer has in relation to agricultural biotechnology. These findings remain relevant for current discussions on gene editing technologies like CRISPR-Cas. Openly discussing these different views on the identity of smallholder farmers is crucial for moving forward in the biotechnology controversy and can inform future attempts to elicit the farmer's voice.
\end{abstract}

Keywords African farmers · Farmer identities · Biotechnology · GMO - Makhathini flats $\cdot$ Johannesburg summit

Koen Beumer

k.beumer@uu.nl

1 Copernicus Institute of Sustainable Development, Utrecht University, Princetonlaan 8a, 3584 CB Utrecht, The Netherlands

2 Science and Society Group, Energy and Sustainability Research Institute Groningen, University of Groningen, Nijenborgh 4, 9747 AG Groningen, The Netherlands 


\section{Introduction}

In this article we investigate how actors involved in genetically modified (GM) crops ascribe different identities to the African farmer. Ever since the first transgenic crops were commercialized in the early 1990s, the possible impact of these crops on the African continent, and particularly on African farmers has been subject to intense academic and societal controversy (Toenniessen 1995; Woodward et al. 1999; Jansen and Gupta 2009). ' 'The African farmer', usually referring to smallholder farmers in sub-Saharan Africa, has emerged as a central figure in this debate, as proponents and sceptics of GM crops have put forward highly diverging accounts of the impact of GM crops on 'the African farmer'. While these discussions can be dated back over twenty-five years, the debate is anything but settled. There are still widely diverging claims about the impact of GM crops on African farmers, ranging from view that GM crops will help to 'eradicate extreme poverty and global hunger' (Flowers 2016) at one end of the spectrum to the view on the other end that GM crops will 'impoverish unto death the farmers' (Cohen-Cole 2008). These discussions are ongoing and have recently expanded to next-generation biotechnologies such as CRISPR-Cas9.

We aim to contribute to the understanding of the longevity and intensity of this debate by identifying the farmers' representations that are implicated in diverging views about the impact of GM crops on African farmers. This adds to prevailing explanations of the GM controversy that have focused the issues of scientific uncertainty and diverging interpretations and assessments of scientific evidence (e.g. Wynne 2001; Levidow and Carr 1996; Levidow et al. 2005; Jasanoff 2005) and on conflicting values and interests that are at stake, revolving around issues such as trade, public trust, and democracy (e.g. Zerbe 2004; Kearnes et al. 2006; Levidow and Carr 2009; Ayele 2007; Beumer 2019). The representation of the farmer, so we argue, is a somewhat ignored but crucial aspect for understanding and moving forward the debate about the impact of GM crops on African smallholder farmers.

In particular, we argue that the figure of the African farmer acts as a boundary object: as a concept that is "both plastic enough to adapt to local needs and the constraints of several parties employing them, yet robust enough to maintain a common identity across sites" (Star and Griesemer 1989, p. 393). Across the board, the African farmer is thought to play a key role in the struggle against food insecurity in Africa. Approximately 78 percent of African people living under the extreme poverty line of less than $\$ 1.25$ a day live in rural areas (Townsend 2015) and the great majority of the rural population in Africa relies on agriculture for a living (FAO 2015). Hence irrespective of one's position with regard to the merits and drawbacks of GM crops in Africa, the impact that the technology has on African farmers is deemed of crucial importance. As such, the shared interest in the African farmer

\footnotetext{
1 Although these early discussions often refer to agricultural biotechnology in general, in practice the focus predominantly resided with genetically modified crops, as other forms of agricultural biotechnology such as marker-assisted breeding and tissue culture were rarely subject to debate. This article therefore focuses on genetically modified crops.
} 
offers a starting point for actors with radically different ethical and normative views on GM biotechnology to enter into conversation about the introduction and impact of agricultural biotechnology in Africa. Representations of the African farmer thus offer a starting point for bringing into sharp focus the different values at play in the controversy on GM crops.

To further enhance this ethical debate, we aim to identify the main fault lines in different views of the impact of GM crops on the African farmer - fault lines that have informed the efforts of various actors to either support or obstruct the introduction of GM crops in Africa. In order to do so, we analysed the representations of African farmers in two prominent moments where expectations with regard to GM crops were contested: the debates at the 2002 World Summit on Sustainable Development (WSSD) in Johannesburg and the discussion about the impact of GM crops on smallholder farmers in the Makhathini flats in KwaZulu Natal, South Africa. These rather different cases allows us to identify the differences in how farmers are represented in debates on GM in Africa. Our findings demonstrate that arguments about the impact of GM crops are related to diverging views on who the African farmer is, i.e. what is important for him or her, and what role the African farmer has in relation to genetically modified crops.

Below, we will reflect on the concept of farmer representation in general, accordingly we describe our methodology and the resulting analysis of our empirical cases. In the conclusion we discuss the implications of our results.

\section{Farmer Representations}

African smallholder farmers are generally far away from the governance of innovation. Yet despite having little voice themselves in the articulation and contestation of expectations, farmers representations nevertheless play a key role in discussions on GM. We will investigate this by drawing upon sociological studies on what is called the 'good farmer'. This literature highlights the importance of representations of the farmer (Burton 2004; Burton and Wilson 2006; Shucksmith and Herrmann 2002; Setten 2004; Silvasti 2003; Saugeres 2002). This literature moves away from studying farmer 'attitudes' and 'opinions' about a particular technology or policy using methods such as farmer surveys and focus groups. Instead these scholars aim to grasp "the cluster of practices, signifiers and relationships that constitute and reproduce what is the culturally valorized understanding of "good farming" in any particular farming context" (Haggerty et al. 2009).

The core message of literature on the 'good farmer' is that representations of the farmer - articulating who the 'good farmer' is - exert influence. In the first place this concerns ideas of the 'good farmer' that circulate amongst farmers themselves. Several studies have highlighted how such representations emerge and are sustained by farmers themselves in their everyday farming practices (Mc Henry 1997; Burton 2004; Soini and Aakkula 2007). For instance the idea that farmers should have tidy fields is maintained in interaction with actual practices to fulfill this ideal. "Consequently, well-maintained and tidy field margins symbolically serve as an indication of 'good farmer"' (Soini and Aakkula 2007). And a study Badstue et al. (2007) 
for instance found that Mexican maize farmers consider 'good farmers' to be those farmers who provide others with seed when they are in need while simultaneously associating the failure to save seed with a loss of prestige. These notions of the 'good farmer' exert influence by stimulating seed savings and thereby diminishing the problem of free riding.

Also representations of the 'good farmer' that are articulated by non-farmers are performative. Several authors have for instance explained the failure or success of agricultural change by highlighting the discrepancy between the role farmers are expected to play in agricultural policies and what farmers themselves consider as 'good farming' (Silvasti 2003; McGuire et al. 2013). Silvasti (2003) for instance found a discrepancy between government definitions of Finnish farmers in terms of production and the view of farmers themselves, who regard the protection of nature as an intricate part of what it means to be a 'good farmer'. And Burton (2004) reversely found that in the United Kingdom the transition to 'post-productivist' roles of farmers collided with the emphasis on production that farmers themselves identified as central to good farming. "Production-oriented roles", so Burton notes, "came to symbolise, both to farmers and to the country, the notion of good farming practices and enabled farmers to claim a high social position as caretakers of the nation's food supply" $(2004,195)$. When agricultural policies aimed to direct farmers towards new 'post-productivist' roles in conservation and leisure, farmers thus faced the threat of losing the role of food producer that gained them social standing and consequently resisted these reforms.

The representations of the farmer thus play an active role in shaping agricultural change, regardless of whether or not those notions of the 'good farmer' correspond to what the farmers themselves articulate to be in their best interest, and regardless of whether the farmers themselves would represent themselves along similar lines. This is particularly important for understanding how the African farmer is constructed and represented in the GM crop controversy by the proponents and sceptics of the benefits of genetically modified organisms (GMOs).

The importance of notions of the 'good farmer' that are put forward by actors other than farmers themselves is particularly relevant for our purposes here, because African farmers themselves are rarely given a voice in the discussion on GM in Africa. This point is pushed home in an insightful 2015 article by Schneider (2015), who explored how the representation of the smallholder farmer in Chinese political and public discourses shifted as Chinese politics moved towards industrial agriculture. Smallholder farmers were increasingly casted as ignorant, backward and inefficient, and were used "to stand in for the ills of China's contemporary agrifood system" (Schneider 2015, 332). Such representations of smallholder farmers "were used to justify the industrialization of agriculture as the "modern" solution to a "traditional" problem" (Schneider 2015, 336). Schneider thus highlights that farmer representations are actively mobilized by other actors in support of their ambitions.

By bracketing the question who the farmer 'really' is, these approaches reveal the political work that representations of the farmer do. Notions of the farmer are not merely means to capture reality by foregrounding particular aspects of what it means to be a farmer, they simultaneously exert influence on agricultural policies and practices. The term 'representation' used in this article serves to capture the 
perspective that these aspects are in fact two sides of the same coin (Latour 2005): the term refers to the accurate portrayal of farmers as well as to the political representation of their interest in the sense of legitimately speaking on behalf of the farmers. Descriptions of who the African farmer is, what is important for the African farmer, and what role the African farmer has in relation to GM crops aim to capture reality and exert influence on reality. It is in this way that we analyse the African farmers are represented in the discussion on genetic modification.

Most of the literature on the 'good farmer' investigates the relation between productivist notions of good farming and the environmental concerns that are increasingly associated with this type of farming (Burton 2004; Burton and Wilson 2006; McGuire et al. 2013; Silvasti 2003). When applying these insights to investigate claims about the impact of GM crops, however, we should also pay attention to the technological side of the story.

In this article we therefore build upon the commonplace assertion in the field of science and technology studies (STS) that technology and society should be considered as mutually shaping each other. This mutual shaping has variably been described in terms of co-production (Jasanoff 2013), co-construction (Latour 1992) or co-shaping (Bijker and Law 1992). What is important for our analysis is the shared insight that not only "a farmer's person, role, and social identities are complex, dynamic, and often context specific" (McGuire et al. 2013), so too is genetic modification. What the technology is, and what impact it may have on African farmers, is itself context specific and subject to various interpretations. Agricultural biotechnologies should not be treated as a black box whose role in changing expectations of African farmers is taken for granted. Instead the roles that are ascribed to African farmers are informed by the particular interpretation of the role and meaning of genetic modification for them, while the role and meaning of GM crops is in turn informed by ideas of the role and meaning of the African farmer.

\section{Methodology}

We traced representations of African farmers in GM crops expectations by gathering extensive literature on two controversies with regard to the possible impact of these crops on smallholder farmers. These controversies pushed actors to explicitly articulate their view of the African farmer: the World Summit on Sustainable Development and the attempts by smallholder farmers in the Makhathini flats, South Africa to adopt $\mathrm{Bt}$ cotton, a GM cotton variety that is made resistant against bollworm, a major pest in growing cotton. Whereas the way the Makhathini flats formed the stage for claims about the impact of GM crops on Africa has already been discussed by Matthew Schnurr (2012), we specifically investigate how farmers were represented in these claims.

Both cases demonstrate diverging views about the impact of GM crops on African farmers that were explicitly articulated, therefore providing a rich body of sources to test our hypothesis that diverging farmers representations play a key role in debates on GM crops in Africa. The cases are different in that the WSSD summit is a single event where farmers representations were articulated in an international 
arena, whereas the Makhathini flats is a case where GM crops were actually introduced amongst a limited group of small-scale farmers in the time-span of well over a decade, providing empirical substance to expectations about the future. Interestingly, whereas both case studies are situated in South Africa and partly overlap chronologically - small-scale farmers were already planting GM crops at the time the WSSD summit was held - different actors were involved in the two controversies and we did not find any cross-references between the discussions. These differences offer thus the opportunity to test whether our hypothesis holds in different contexts and subsequently provides a more complete image of the role of representations in the debate on GM crops.

Our methodology consisted of a variety of sources containing statements about the impact of GM crops on farmers. We therefore we made use of various search strategies. Besides using academic databases like EBSCOHOST, Web of Knowledge, and Google Scholar, also regular search engines like Google were used. We made sure to use a variety of different keywords, including 'genetically modified organism', 'genetic mod*', 'GM', 'LMO', and 'biotech*', as well as 'farmer', 'peasant', 'agriculturalist', 'smallholder' and 'producer'. All sources were included that discussed African farmers in relation to GM crops and WSSD or in relation to GM crops and the Makhathini flats. Sources that solely discussed farmers apart from the African context were excluded, as were sources that did mention African farmers but where it was not possible to derive a meaningful representation of the African farmer in relation to GM crops (e.g. sources that only mention African farmers in the attendance lists, or that mention African farmers but not in relation to GM crops). The academic and non-academic databases were searched until saturation was reached (Rijnsoever 2017). This search strategy was complemented by a snowball method. We actively searched for other documents authored by the actors that we encountered, pursued references to other actors or statements mentioned in the texts that we found, and searched for further documents on the websites of each of the organizations involved. This resulted in over 150 sources of various kinds, including scientific articles, newspaper articles, reports, and websites.

Subsequently, in the resulting set of documents of both the Makhathini flats and the World Summit, we coded and analyzed expressions that articulated expectations about the impact (or lack thereof) of GM crops on African farmers. Accordingly, we clustered similar codes into categories of farmer representations. This process coding, interpreting, and categorizing involved a continuous going back and forth between the empirical material and the resulting codes and categories, thereby slowly refining our findings, described below.

\section{The World Summit on Sustainable Development}

The World Summit on Sustainable Development (WSSD) took place from August 26 to September 4, 2002, in Johannesburg, South Africa, exactly ten years after the successful Earth Summit in Rio de Janeiro. The event was organized by the United Nations in order to bring together governments, industries, and non-governmental organizations to discuss sustainable development. 
In the midst of these discussions, one particularly heated debate stood out: the debate on the merits and drawbacks of GMOs, and the effects of GM crops on African smallholder farmers in particular. The use of GM crops in sub-Saharan Africa had become a particularly pertinent issue around the time of the WSSD. In the months leading up to the summit several million people in southern Africa were facing starvation after harvests had failed. When the United States subsequently offered food aid, this was controversially rejected by several southern African countries, most notably Zambia, because of the presence of genetically modified food in the aid packages. In the ensuing debate, commentators on one side blamed the United States of trying to further their trade interests over the back of starving people and commentators on the other side pointing out that Zambian politicians rejected genetically modified food fearing that it may have a detrimental health effect while their citizens were dying (Zerbe 2004).

It was in this tense moment that various actors used the WSSD as a platform to discuss the future impact of genetically modified organisms on smallholder farmers. The debate was sharply divided in two opposing camps, which can be called proponents (mostly consisting of industry organizations and lobby groups) and sceptics (mostly consisting of international non-governmental organizations). The two camps made diverging and often opposing claims about the expected impact of genetically modified organisms on smallholder farmers and in doing so co-produced visions of GM crops and African farmers in very different ways.

\section{Proponents: Freedom of Choice}

During the Johannesburg summit, a key point of contention in the representation of farmers was freedom of choice. Proponents of GM crops articulated this at various moments and in different ways, such as with a farmers march that was organized in the run-up to the summit to voice the support of smallholder farmers to genetically modified organisms. "The demands of farmers", so it was reported, "include the freedom to grow any crop of their choice" (Shikwati 2002). The central argument was that farmers "should not be denied the freedom to test for themselves the economic and technological viability of any new technology, including agricultural biotechnology" (Okonski 2002). Without necessarily specifying the future impact of GM crops on smallholder farmers, this perspective articulated 'good farmer's as actors who should be able to decide for themselves what technology works best for them.

According to GMO proponents, African farmers currently lack the freedom to choose between different technologies. The fact that smallholder farmers at that time predominantly used technologies other than genetic modification was cast as the result of such constraints, rather than being a reflection of their choice. "Millions of people rely on backbreaking labor and low-intensity subsistence farming, not out of choice but out of necessity. (...) But given the choice, poor rural farmers seize the opportunity to use modern technologies to improve their agricultural productivity" (Okonski 2002). One controversial Indian farmers' representative even went as far as to say that "traditional organic farming led to mass starvation in India for centuries" 
(Matthews 2003), concluding with the claim that all this could be counteracted if only farmers had the choice to use new technologies. The 'good farmer', so the assumption went, would make use of freedom of choice to use modern technologies.

GM crops, in this context, are expected to offer new opportunities that may help smallholder farmers in general and African farmers in particular in navigating their challenging circumstances. It was for instance argued that as long as developed countries would refuse to open their markets to the products of developing country farmers, as seemed likely during the Johannesburg summit, smallholder farmers "must become more self-reliant, which means using the latest technologies" (UPI 2016). And it was argued that GM crops could help smallholder farmers deal with challenges springing from climate change. The president of the farmers union in Gujarat, India was for instance quoted saying that "without new technologies, such as GM seeds - which are more drought resistant - (...) it's harder to vary growing seasons and maintain crop diversity, which protects against extreme weather" (UPI 2016).

The great majority of arguments, however, explicitly pointed out that the freedom to choose genetically modified organisms would benefit smallholder farmers economically. One organization supporting GM crops noted: "the farmers, being the most important stakeholders, must have the freedom to decide for themselves the appropriate strategies for staying competitive in the world market, and regaining economic viability" (Mitra and Okonski 2002 2002). This economic argument for freedom of choice was most clear during the farmer's march, in which smallholder farmers were joined by street hawkers and others in their call for "freedom to trade". The organizers of the march noted that "as First World delegates sat in conference halls and debated, African and Indian farmers hit the streets of Johannesburg to tell the world what they really want and need - not sustainable development but economic growth" (Shikwati 2002).

The benefits of GM crops were mostly not put forward as an objective in itself but rather as a justification for the importance of granting farmers the choice between different technologies. This choice became meaningful thanks to the presumed benefits of GM crops but the emphasis firmly remained on the farmer's choice, arguing that farmers themselves should take decisions about using technologies, not the people discussing the technology, like governments or non-governmental organizations.

In putting forward the vision of smallholder farmers as actors in the marketplace, proponents also regularly elicited farmer's voices, hence explicitly combining the two different notions of representation - i.e. accurately portraying farmers and representing their interests. For instance proponents time and again drew upon quotes from farmer representatives at the farmers march. This came together in a Nature Biotechnology article, written shortly after the Johannesburg summit, by Val Giddings, vice-president of the Biotechnology Industry Organization (BIO). What made the Johannesburg into a turning point in the GMO discussion, he said in reference to the farmer's march, was that "for the first time, we saw significant numbers of real, live, developing-world farmers" were "speaking for themselves" (Giddings 2002, 1081). In support of this claim he quotes Chengal Reddy, the leader of the Indian Farmers Federation, saying that farmers demand the freedom to choose new technologies. 
Sceptics were quick to criticize these attempts to represent the farmer's voice, arguing that the supposed farmer's representatives were not genuinely representing smallholder farmers. Journalists present at the farmers march observed that many farmers wearing pro-GMO t-shirts and carrying English banners could not even speak English. Others questioned how poor farmers from the Philippines and India managed to travel to Johannesburg. Quite some mud was slung back and forth, with sceptics for instance not only pointing out that the often-quoted farmer's representative Chengal Reddy in fact represented a group of big commercial farmers, but also that his father once said that "there is only one thing Dalits [members of the socalled 'untouchable' caste] are good for, and that's being kicked" (Matthews 2002). What this had to do with GM crops remained unclear but for the argument here it demonstrates the importance that both sides attributed to have smallholder farmers themselves supporting their representation of the farmers identity, up to the point of making personal attacks to discredit the truthfulness of proponents' claims. ${ }^{2}$

GMO proponents at the Johannesburg summit thus represented the farmer as an actor who is in the best position to make decisions for him or herself. 'Freedom of choice' between different technologies available at the market was put forward by them as the best mechanism for mediating the relation between farmers and GM crops. The freedom to choose between different technologies was considered to be important for farmers to pursue their economic objectives and GM crops were put forward as another tool in the toolbox of farmers as they seek to work their way out of poverty.

The proponents' emphasis on the 'freedom-of-choice' positions of the smallholder farmer fits to familiar neoliberal lines whereby the individual farmer is cast as key in solving development problems through his or her economic decisions, assuming that the 'good farmer' would choose to purchase GM crops if only he or she has the opportunity to exercise this choice. The dire situation that smallholder farmers are in is thus exclusively attributed to market failure in the provision of agricultural technologies. This portrayal subsequently backgrounds (or takes for granted) the relations between the farmers and families, communities, corporations and donors that may be implicated in this representation of the farmer as an actor in the market place. By reducing the issues at stake in the discussion over the impact of GM crops on smallholder farmers to an issue of individual choice in the market place, however, broader or structural issues are left unaddressed. It was from this latter perspective that sceptics positioned the farmer.

\section{Sceptics: Structural Factors}

In the discussions at the Johannesburg summit, GMO sceptics consistently pointed out that adopting GM crops would create a particular relationship between

\footnotetext{
${ }^{2}$ In this article we are not investigating in whether or not these representations of the farmers voice are accurate or not. For the purposes here it is important to point out that the pains through which sceptics went to give the farmer a voice signals an awareness of biotechnology proponents of the importance that the subjectivities they attribute to farmers coincide with those held by the farmers themselves.
} 
smallholder farmers and corporations supplying these technologies. Farmers, in this view, are constructed as actors who are defined by the relations of which they are a part. The relationship with corporations that will be instantiated by purchasing GM crops, so sceptics expected, are characterized by dependency on these corporations. Sceptics deemed such corporate control worrisome because in their view large corporations do not work in the interest of farmers. The report of a gathering of civil society organizations noted that "the majority were not convinced that multinational corporations such as Monsanto had any other purpose other than profit and would not necessarily take the interests of the African farmers at heart" (Biotechnology and GMO commission 2002). Rather than enabling farmers to gain economically by providing them with the freedom to choose between different technologies (an argument put forward by GM proponents), GM crops in this reading serve to tie the farmers to multinational corporations in order to make them work in the interest of global capital. The 'good farmer' is hence a farmer avoids these detrimental ties.

This perspective often focused on the role of intellectual property rights. For instance a group of civil society organizations formally declared their opposition to the patenting of life and to the patenting of crops and seed, because they were concerned about the removal of control of food production from local communities and farmers to multinational corporations (Biowatch 2002). In particular, sceptics viewed the system of intellectual property rights as a direct challenge to farmers' rights. The Small-Scale Farmers Convergence organization for instance noted that "land, water, plant and animal genetic resources and minerals have been communally owned throughout generations and, therefore, should never be transferred to private ownership" (Small-Scale Farmers Convergence 2002). And the Johannesburg Declaration stated that "we believe that community rights over biodiversity and indigenous knowledge are collective in nature, and therefore cannot be privatised or individualized" (Biowatch 2002).

The argument about dependency and control was strengthened by the view that the use of GM crops by farmers will not always be the result of a free choice by farmers acting in a market place. The controversial American offer to provide GM food aid to Zambia was repeatedly used as evidence to press home this point. Sceptics argued that peasant farmers and indigenous peoples are opposed to GM crops but that the United States denied these farmers the freedom to reject these technologies by using "coercive techniques" to "force acceptance of GM food and crops by Southern nations on the eve of the World Summit on Sustainable Development" (Mittal et al. 2002). The use of such 'coercive techniques' directly contradicted with the importance that proponents earlier attributed to the freedom to choose between different technologies (Mittal et al. 2002). In articulating this criticism, sceptics did not argue that the technology itself was the main source danger of dependency. Rather they pointed to the ownership that corporations could claim over the genetically modified crops and the 'coercive techniques' used by them, thus taking both the farmer and the technology out of their isolation and pointing to the systems that they are part of.

GM crops, in this view, also will disrupt fragile systems that function reasonably well for farmers. The small-scale farmers convergence for instance notes that "that the rich knowledge, best practices and technologies developed by us farmers 
in providing farming, healing, worship and marketing of our farm produce (...) form the core of the our existence and livelihood" (Small-Scale Farmers Convergence 2002). Whereas GMO proponent discarded traditional farming technologies as backward practices 'recognizable to Jesus Christ' (Bate 2002), sceptics instead cast these technologies as being particularly well-suited for African farming conditions because they were developed and put to practice in those very conditions. Rather than representing the farmer as a passive recipients of technologies provided by the market, as proponents would have it, this view constructs the 'good farmer' as someone who is him- or herself a crucial actor in the development of suitable technologies. As one report claimed: "African farmers are skilled and knowledgeable and are responsible for the vast majority of agricultural innovation that has succeeded in Africa" (Kuyek 2002).

While sceptics do not expect that existing practices and technologies will suffice in lifting the farmer out of poverty, their argument is that "research should focus and build on this knowledge and practice" (Small-Scale Farmers Convergence 2002). GM crops, in contrast, are seen by them as being ill-suited to the challenging conditions in which African farmers have to operate: "the social, economic, and political conditions throughout Africa are as ill-suited as the ecology to 'breakthrough' technologies" (Kuyek 2002). By nevertheless introducing GM crops in this complex ecology, so the argument goes, GM crops can disrupt local practices that help farmers to sustain themselves. As a report by GRAIN summarizes, GM crops "threaten to further undermine the fragile agricultural systems that these [African smallholder] farmers depend upon" (Kuyek 2002).

Just like proponents tried to mobilize farmers in support of their claims, also sceptics claimed to speak on behalf of the farmers and drew support from instances where farmers were considered to speak for themselves. Various meetings were organized where farmers organizations were invited to articulate their views, and publications often included various quotes by farmers. And just like we earlier saw sceptics trying to discredit proponents' claims to speak on behalf of the farmer, proponents likewise tried to discredit farmers' voices that did not align to their own ideas about the impact of GM crops on African farmers. By pointing out that developing country farmers who articulated their opposition to GM crops were somehow connected to international organizations opposing genetic modification, those farmer representations were set aside as spokespersons for European donors, unable to represent the 'good farmer'. Paarlberg for instance repeatedly dismissed GM skeptical farmers' representations in this fashion, noting that "the Johannesburg summit (...) gave international NGOs an opportunity to put anti-GMO words into the mouths of local African farm organizations" (Paarlberg 2008). By suggesting that authentic voices of developing country farmers can only be attained from those farmers who are no way supported by foreign connections, proponents simultaneously represent smallholder farmers as actors who are isolated from the rest of the world, as actors that are only authentic when they are not defined by their relationships.

Thus the issue of 'freedom of choice' is central to both the proponents' and the sceptics' view of the African farmer. But the choice they envision structures the relation between farmers and GM crops in radically different ways: it is not only about the freedom to choose between different technologies but also between different 
relationships that weaken or strengthen the capacity of farmers to sustain themselves. Whereas sceptics describe the existing technologies and practices used by farmers as being well-adapted to the farmer's local context and situate the farmer as a community member, GM crops in this view are ill-suited to the local context and are expected to tie farmers as individuals to multinational corporations in ways that take away the control, freedom of choice, ownership or right to determine their own lives - qualities that are key to the 'good farmer'. The Johannesburg Declaration aptly summarizes this point: "we oppose the current push towards globalisation that is driven predominantly by commercial interests and which undermines our cultures and our capacity to sustain and control our livelihoods" (Biowatch 2002).

\section{The Makhathini flats}

At the WSSD, both optimistic and pessimistic expectations about the impact of GM crops on smallholder farmers were mostly based on extrapolation from largescale farmers' experiences with modern technologies. This is rather different in the Makhathini flats discussion. The Makhathini flats is a small region in the eastern tip of KwaZulu-Natal, South Africa, tucked in between the Indian ocean on the east, Mozambique in the north, and Swaziland in the north-west. In the late 1990s and early 2000s, the region witnessed the first instances where smallholder farmers in Africa started growing genetically modified crops. This offered for the first time the opportunity to empirically study the effects of genetically modified crops on smallscale farmers. The Makhathini flats consequently became "the epicenter of a heated debate about growing genetically modified (GM) crops in Africa" (IRIN 2006).

The stakes of the discussion were high. The successful adoption by smallholder farmers was described as "excellent publicity for the companies involved" (FAO 2004, 96). With European resistance to genetically modified crops unchanging, the debate further was pertinent for the biotechnology industry because the African continent provided an important potential growth market. Both GMO proponents and sceptics subsequently came to describe the smallholder farmers in the Makhathini as representative for the African farmer in general. For instance one paper uses a survey of 100 Makhathini farmers to answer the question 'can GM-technologies help African smallholders?' (Beyers and Thirtle 2003). And an opposition group called the African Center for Biosafety reaffirmed this generalization when it observed that "there's a lot at stake for Monsanto because if they can't get it right here, where it's commercially grown by small-scale farmers, they can't sell it to the rest of Africa" (IRIN 2006). Both proponents and sceptics thus extrapolated the experiences of the Makhathini farmers to articulate expectations for African farmers in general.

Claims about the impact of GM crops on Makhathini farmers were put forward in various media, just like the debate surrounding the Johannesburg summit, but the most important arena for this debate were academic journals, and the most visible actors in this debate were scientists - in rather strong contrast to the WSSD discussion. Although this perhaps may have led to less overt opposition between GMO supporters and their adversaries, also authors of academic papers often took a clear 
stance either in support or in opposition to GM crops. And also in these academic discussions, African farmers were represented in different ways.

As we will see, rather similar fault lines in the representation of the 'good African farmer' emerged. At the Johannesburg summit the fault lines in representing the 'good farmer' revolved around the tension between choice and the lack thereof, between structure and agency; in the Makhathini debate GM crops and the African farmer were co-produced in terms of rational choices versus structural and institutional constraints.

\section{Proponents: the Farmer as a Vulnerable Entrepreneur}

The first studies that assessed the impact of GM crops on Makhathini farmers predominantly focused on the economic effects of growing Bt cotton for smallholder farmers. These studies mostly found positive effects. Describing agriculture as "an important source of income in the Makhathini area" (Ismael et al. 2001), the majority of these studies focused either on productivity and gross margins or on farmer perceptions thereof. Studies focusing on productivity showed that GM crops increased yields and profits, whereas studies on gross margins highlighted that farmers adopted GM crops because of increased yields and reduced pesticide use. In an online comment, Thomson (2000) for instance claimed to have found a $20 \%$ yield increase in the 1998/1999 growing season compared to conventional cotton and a two-fold yield increase in the 1999/2000 growing season "in some areas" (Gregory et al. 2002, 32). Bennett et al. (2003) concluded on the basis of a farm-level survey of 32 small-scale farmers that the reduced number of insecticide applications gave Bt cotton farmers direct cost benefits of SAR416 (\$51) per hectare per season. Kirsten and Gouse (2002) found small-scale farmers indicated pesticide savings as the second most important benefit, after increased yields. And based on a survey of the 1998-99 and 1999-2000 growing seasons for 100 smallholder farmers, Beyers and Thirtle (2003) conclude that "higher yields and lower chemical costs outweighed higher seed costs, giving higher gross margins" (2003, 2).

The outcomes of these studies were positive but they resisted overly optimistic conclusions about the future. The differences in yields and profits between Bt cotton farmers and conventional cotton farmers varied from growing season to growing season. Similarly, whereas some researchers also found decreased pesticide costs for farmers growing Bt cotton (Ismael et al. 2002), others found that Bt cotton farmers did not significantly decrease their overall pesticide use (Hofs et al. 2006; also see Shankar and Thirtle 2005). And using data from the cotton gin, Gouse et al. (2005) did not find Bt cotton to have any clear yield advantage. The outcomes showed "that GM crops are not miracle products which alleviate poverty at a stroke" (Morse and Mannion 2009, p. 225). Yet when taking all results together, most scholars concluded that there was ground for 'cautious optimism' (Ismael et al. 2001) regarding the positive impact of GM crops on African smallholder farmers.

By predominantly focusing on the economic impacts and economic motives for adopting GM crops, these studies represent the 'good farmer' as a 'profit-maximizer' - as an actor in the market place for whom income is the most important 
consideration. None of these studies for instance investigated the impact of adopting GM crops for smallholder farmers' ambitions to move to the city (as has been widely reported in South Africa) or on the community's capacity to sustain their cultures (which we saw was prominent in farmer representations by GMO sceptics at the Johannesburg summit). The 'good farmer', in other words, was focused on maximizing profits from the farm.

This representation of the farmer-entrepreneur could also be witnessed in various instances where authors use the adoption of Bt cotton as evidence for its benefits for smallholder farmers. Considering that farmers are in the best position to know what their needs are, so the argument went, the rapid uptake of the technology by smallholder farmers demonstrates the benefits that the technology brings to them - a claim that is posited on the condition that the 'good farmer' is indeed a profit-maximizing entrepreneur with access to complete information. In this light Morse and Mannion (2009) observe that farmers do not care what the technology is or does as long as it maximizes their profits: "whether the resistance [to pests] derives from a bacterial source or conventional breeding would not be an immediate issue for Makhathini farmers. What they recognise are the gains from growing Bt cotton, and rapid adoption is testament to its popularity" (Morse and Mannion 2009, 243).

At first sight, the focus on the farmer as a rational actor in the market place seems to imply that GM crops increase gross margins for the farmer-entrepreneur regardless of the size of his or her farm, and regardless of whether that farm is located in Africa or elsewhere (see Fischer 2016). Yet subsequent studies instead represented African smallholder farmers as a distinct category of farmers. This was done, first of all, by highlighting aspects of the technology that are particularly beneficial for African farmers. Kirsten and Gouse (2002) for instance point out that pesticide savings are distinctly important for smallholder farmers. In contrast to large scale farmers who can afford tractors, small-scale farmers have to walk between 10 to $20 \mathrm{~km}$ for every hectare to spray pesticide with a knapsack sprayers on their back s. As a result, "by the time a farmer has noticed bollworms, bought pesticides, and started to spray, severe damage has already been done" $(2002,7)$. These arguments were often accompanied by the expectation that decreasing pesticide use also potentially improves farmer's health (Beyers and Thirtle 2003; Bennett et al. 2003). Although the economic frame remains dominant in these articulations of the African GM cotton farmers, the health benefits of reduced spraying similarly provides a distinct aspect of African smallholder farmers, who are especially confronted with health risks of pesticides, and therefore especially stand to benefit from GM crops.

The African farmer was also represented as distinct from other farmers by highlighting indirect consequences of adopting the technology that are specific to smallholder farmers. Morse and Bennett (2008) for instance investigated the impact of adopting Bt cotton on household livelihoods by conducting a survey amongst 100 'resource-poor' farmers in the Makhathini Flats. Of those farmers who reported higher incomes from Bt cotton, most indicated to have used this income to invest in the education of their children, as well as to produce more cotton, lessen the need for credit, and 'spend on themselves' - expenditures that highlight the dire situation that they may be in. 
Other authors in turn articulated the consequences of increased yields and profits in terms of resilience, describing the profits made from growing GM crops as resources for mitigating various vulnerabilities. For instance higher income was expected to enable smallholder farmers to "emerge as more resilient in absorbing price fluctuations" (Bennett et al., 123), to lessen farmers' dependency on food aid in a world where more than enough food is produced worldwide but famines still occur (IRIN 2006), and to increase farmers' resilience to environmental stress. The latter is considered an important benefit for "risk-prone, resource poor farmers" (Ismael et al. 2001). Proponents in the Makhathini debate hence represent African farmers as entrepreneurs who are subject to various vulnerabilities, from markets to the weather, and from food infrastructure to the availability to credit. Considering these specific conditions, the 'good African farmer' is a rational actor with access to complete information who may him- or herself overcome the constraints s/he faces thanks to the benefits derived from GM crops in terms of profits and pesticide savings.

Proponents consider the individual farmer, or the individual farm, as the most relevant level for analysing the impact of GM crops on smallholder farmers. It is from this perspective that GM crops are expected to help farmer-entrepreneurs to increase their income and increase their resilience. Proponents, in other words, pointed out that within the constraints faced by smallholder farmers, GM crops will be a viable and profitable choice that may benefit their profits, livelihoods, and health, which in turn may help to overcome structural constraints and diminish their vulnerability.

\section{Sceptics: The Farmer as a Ball in a Game of Circumstances}

Whereas GM proponents highlighted the vulnerabilities of African farmers, efforts to address the causes of these vulnerabilities were deemed to lay outside the scope of farmer's agency. They were subsequently not addressed by GM proponents. However, GM sceptics, on the other hand, who mostly consist of different scientists along with several civil society organizations, mainly focused on these contextual constraints.

One key difference between the two sides in the Makhathini flats discussion is that sceptics zoom out and look at the bigger picture of those constraints. Some authors for instance highlighted that drought was the main issue cotton farmers in the Makhathini flats and that this was not addressed by Bt cotton (McAllister in IRIN 2006). Others argued that the reliance on cotton itself was a problem. They pointed out that market price is the best measure of success for a cash crop like cotton and argued that this price was suppressed by the monopoly of the ginning companies. These companies mechanically separate cotton fibers from their seeds and also acted as intermediaries between farmers and the market. In the Makhathini flats the ginning company had a monopoly position, which prevented farmers from getting a fair price for their produce (Kuyek 2002). It was concluded that the reliance on cotton was not the result of a free choice but instead, that farmers were forced to grow cotton because of the dry and hot weather and the absence of governmental 
investments in irrigation technologies that could enable farmers to grow other crops (Mabika in IRIN 2006; Witt et al. 2006).

This represents the African farmer in a rather different way. Whereas proponents focus on the farmer and consider what a farmer can do within his or her (constrained) situation, sceptics focus on actors other than the farmer who supposedly are in a better position to either maintain or take away such constraints, thereby foregrounding the farmer as a powerless actor who is not able to change his or her own destiny. The representation of the 'good farmer' as a rational decision-maker is not necessarily contested, but sceptics expect that such agency to make rational decisions is meaningless in the face of structural factors that farmers have no control over.

This also came to the fore after a severe complication emerged to the proponents' scenario: although smallholder farmers had rapidly adopted Bt cotton in the early years, they just as rapidly abandoned the technology in later years. At the height of the Bt cotton adoption between 1998 and 2001, when most studies on the impact of Bt cotton on smallholder farmers were conducted, over 3000 smallholder farmers were reported to grow Bt cotton (Schnurr 2012). This accounted for approximately $90 \%$ of smallholder farmers in the area (Smale et al. 2006). By 2011, however, this figure had dropped to a mere 200 smallholder farmers and the area under cultivation with Bt cotton had declined by over $90 \%$ (Schnurr 2012). With the technology allegedly the same, this raised a new set of questions about the impact of GM crops on smallholder farmers. Apparently increased yields and decreased pesticide usage were not sufficient for explaining the adoption or rejection of a technology, so several authors pointed out.

Instead a group of different scientists suggested that the institutional context of the farmers and Bt cotton provided a better explanation for the success or failure of GM crops for African farmers. In particular, several studies by Marnus Gouse highlighted the crucial role played by the monopsonistic local cotton ginnery, called Vunisa (Gouse et al. 2003). Vunisa was not only the sole provider of seed and pesticide and the sole purchaser of cotton in the Makhathini area, it also provided smallholder farmers with extension services and with easy access to credit from the Land Bank to buy seeds and pesticides by allowing them to use the forthcoming crop as collateral. It was argued that this monopsony along with the provision of credit helped to explain the rapid uptake of Bt cotton amongst smallholder farmers (Gouse et al. 2005; Gouse et al. 2008). In the early 2000s, however, a new cotton ginnery was established in the region, the Makhathini Cotton (Pty.), Ltd. (MCG). Many smallholder farmers who had produced Bt cotton using the credit from Vunisa decided to deliver their harvests to the new company, often defaulting the loans given by Vunisa (Gouse et al. 2008). Vunisa suffered substantial financial losses and eventually left the region while the new ginnery did not provide credit (Morse and Bennett 2008), leaving only the some older smallholder farmers in the position to continue growing Bt cotton using their pension money to purchase the seeds. The number of smallholders farmers growing Bt cotton increased again after the KwaZulu-Natal Department of Agriculture made more credit available in 2005 but those same numbers declined again after these subsidies were discontinued in 2006 (Schnurr 2012). 
Regardless of whether one considers yields, income, labor or health as the most important impact of GM crops on African farmers, these studies highlighted that the technology only had such impacts under particular institutional conditions such as credit opportunities - conditions over which the farmers themselves had very limited control. These authors subsequently represent the farmer in terms of their institutional context, just like the sceptics in the discussions at the Johannesburg summit. The representation of the 'good farmer' in the Makhathini flats revolved around themes of dependency and choice - themes that were also central to sceptics at the Johannesburg summit. One civil society organization for instance used the recognition about the importance of the institutional context in the Makhathini flats to conclude "that the enthusiasm around GM technology is misguided" (Yoke Heong 2006). It noted that "the adoption of GM cotton by farmers is driven by the lack of choice facing them and does not reflect farmers' endorsement of GM technology" (Yoke Heong 2006). And another author critical of claims about the positive impact of GM crops on African farmers wrote that:

"Choosing what to grow happen[s] in a context. What happens on that stage is shaped by its most powerful actors. (...) Farmers in Makhathini aren't being given the choices they really want. Just the ones that are most profitable to those who control the food system" (Patel 2012).

It should be noted that this is not necessarily an argument against GM crops. Morse and Bennett (2008) for instance point out that the dependency of farmers on companies is also enabling. According to them, the fact that Vunisa acted "as both a monopolist supplier of seed and pesticide and a monopsonist purchaser of cotton in the Makhathini area" not only made the farmers dependent on the ginning company but also enabled farmer "to access this technology that has resulted in such rapid adoption" (p. 4). The fact that the new ginning company's lack of credit provision forced poorer farmers to stop growing cotton "would have occurred irrespective of the widespread adoption of Bt cotton" (Morse and Bennett 2008, p. 6). These authors, writing from the perspective of the farmer-entrepreneur, expect that farmers will be dependent on companies one way or another and hence separate the institutional context in which the farmer is embedded from the benefits or drawbacks of agricultural technology. For sceptics on the contrary, who defined the 'good farmer' much more by his or her relationships to the contextual setting, the importance of the Makhathini institutions strengthened their expectation that GM crops are by definition accompanied by relations of dependency and control that will eventually diminish the farmer's capacity to sustain him- or herself.

\section{Conclusion}

For well over two decades, scientists, politicians, administrators, civil society workers and farmers have made diverging claims about the way GM crops will impact developing countries in general and African farmers in particular. In making these claims, actors put forward ideas about who the African farmer is, what is important for the farmer, and what the role of the farmer is. This article aims to elicit the various ways how claims about GM crops and African farmer representations 
are co-produced in these discussions. We have therefore investigated two pivotal moments in which the fault lines between competing farmer representations were clearly visible. We found that that in these two discussions, proponents and sceptics represented African farmers in very different ways.

GM crop proponents at the WSSD chiefly represented the 'good farmer' as an economic actor for whom the main concern is to have sufficient choice between different technologies so as to pursue economic objectives. The discussion about the Makhathini farmers similarly represented of the 'African farmer' as an individual in the market place, as an entrepreneur with access to complete information. The benefits offered by GM crops in terms of profits and pesticide savings is expected to enable the farmer-entrepreneur to overcome various external vulnerabilities, like market prices, the weather, and the availability of credit.

This representation of the African farmer has underpinned efforts to support the introduction of GM crops in Africa ever since. For example the African Agriculture Technology Foundation, a foundation set up in 2002 by the Rockefeller Foundation, USAID and DFID to promote the introduction of GM crops in Africa, recently formulated their mission as providing "better access to agricultural technologies" in order to "boost the productivity of smallholder farmers" (AATF 2019). Similarly, the Genetic Literacy Project dismissed concerns over corporate control over GM by stating that the better question to ask is "how much economic freedom farmers have to choose seeds" (Randall 2014). In each of these cases, the African farmer is once more put forward as an entrepreneur focused on productivity growth and income, who would use GM crops if only s/he would have the choice. Even more recently, these farmer representations are spilling over to discussions on the latest biotechnology tools, like CRISPR-Cas9, ZFN, and TALEN, where emerging discussions about their role for food security almost exclusively focus on farmers' income, productivity gains, and the affordability of seeds (e.g. Ma et al. 2018; Zaidi et al. 2019). Sceptics reversely highlighted the importance of the relations that farmers are engaged in and argued that the ability of 'the African farmer' to sustain him- or herself is based on their membership of local communities who have ownership and control over their own seeds and technologies. GM crops, in this view, are expected to enlist farmers in the interest of global capital at the expense of a community system that is well-adapted to their local conditions. The farmers' experiences in the Makhathini flats was further used to criticized the view of the 'good farmer' as an individual in need of technological choices. The choice between different technologies are meaningless for farmers, in this view, as the their ability to make rational decisions is overridden by various structural and institutional constraints.

These representations of the African farmer can also be found up to this day. For example in 2020, several civil society organizations criticized the application for genetically modified cassava in Kenya by arguing that this will interfere with the seed systems that are well-adapted to the conditions of small-scale farmers (Maina et al. 2020). At times nearly the exact same terms are used that we found in the WSSD and Makhathini flats, such as the Ugandan GM sceptic stating that "farmers in Uganda are worried about the power to control the seeds" (Doucleff 2013) and arguing that when smallholder farmers have to buy seeds from a company, they would enter a relation in which "they would have no rights" (Doucleff 2013). Each 
of these arguments builds upon the view of African farmers as members of local communities whose own technologies are well-adapted to their local environment. The representation of African farmers as crucial actors in the development of suitable technologies has furthermore informed several GM sceptical organizations to support agro-ecological approaches that aim to further improve "local farming practices adapted to the local ecology over millennia" (Ashton 2012; and e.g. see Williams et al. 2014; CheThoener 2019).

Also with GM sceptics we see the representations of the African farmer spilling over to discussions on genome editing. The most prominent example of this is the recent call for a moratorium by the African Centre for Biodiversity, who draw upon this representation of the farmer when arguing that genome edited crops will destroy local seed systems and make African farmers dependent on foreign corporations (ACB 2020). The different representations of the African farmer that we identified in discussions at the Johannesburg World Summit and the Makhathini flats hence reverberate up to this day. The different representations of the African farmer brings to the fore the 'farmer-multiple', to paraphrase Annemarie Mol (2003). This demonstrates once more that the controversy about GM crops is not only about the potential risks that such technologies might pose to human health and the environment. Numerous scholars have already argued that the tendency to focus on issues of risk to human health and the environment unrightfully suppresses more structural issues that are at stake in introducing GM crops, from the future of the global food system to soft impacts related to aesthetics and religion, and from the direction of agricultural research to religious issues about the modification of life (Scoones 2008; Levidow and Carr 2009; Wynne 2001). We add to this list that also the very idea of what it means to be a 'good farmer' is at stake.

We suggest that the co-existences of these diverging representations of 'the African farmer' in relation to the impact of GM crops on developing countries can be better understood using the concept of a boundary object. A boundary object (or in our case rather a boundary figure) refers to a figure whose meaning is sufficiently flexible for different groups to adopt it to their local needs, while being sufficiently robust to allow these different groups to relate (Star and Griesemer 1989). The figure of the African farmer similarly allows actors to ascribe widely diverging identities and practices to him or her while simultaneously having a sufficiently robust meaning for these actors to communicate to each other.

The fact that similar fault lines were found despite the clear differences between the WSSD and Makhathini debates, gives an indication of the strength of the 'African farmer' as a boundary object. Whereas at the World Summit on Sustainable Development, claims were mostly made by industry organizations and civil society organizations, in the Makhathini flats farmer were predominantly represented by scientists in academic journals. Yet in both cases highly similar fault lines were found in farmer representations, suggesting that the figure of the 'African farmer' can serve as a meeting point for bringing together different types of societal stakeholders, in very different settings.

The strength of this boundary object offers a foundation for actors with radically different ethical and normative views on GM crops in Africa to enter into conversation. We would like to make one concrete suggestion for using this boundary object 
to move the debate forward: giving African farmer themselves a voice. Building on the shared understanding of the importance of the African farmers by both GM proponents and sceptics, we believe that the voice of the farmers themselves can move the debate in new and constructive directions.

Importantly, such attempts to elicit the farmers voice can only make a constructive contribution to the debate if they take into account the main fault lines in the way the African farmer is represented, as identified in this paper. There are various methods for eliciting farmer's voices, including farmer surveys (Soleri and Cleveland 2001; Carpenter 2010), focus groups (Beckwith et al. 2003; Lewis et al. 2010), and responses to hypothetical scenarios (Schnurr and Mujabi-Mujuzi 2014; Soleri et al. 2008). Yet such methods are inevitably also informed by particular ideas of the 'good farmer' and may subsequently fail to capture factors that are considered relevant from the perspective of alternative notions of the 'good farmer'. For example actors who consider the 'good farmer' primarily as an actor in ensuring national food security may use surveys to ask African farmers whether the use of GM crops will increase or decrease farmers' yields. While this may show the desirability or undesirability of GM crops from the perspective of the farmer as a key agent in securing national food security, such expectations are unlikely to convince actors who consider the 'good farmer' first and foremost as a guardian of biodiversity. For them, after all, the views of farmers on the possible impact of GM crops on biodiversity are most important, which are not per se captured in farmers' yield perceptions. Reversely, focus groups that elicit the farmers' views on how local seed systems are affected may be useful for those who see the 'good farmer' as an actor who has a right to save seeds but is unlikely to speak to those actors who consider these changes to be of inferior importance compared to the farmer's freedom to choose between technological alternatives. The diverging representations of the African farmer, as e.g. identified in this paper, can hence be used as a basis to improve methods for eliciting the farmers' voice - attempts that do not reduce the farmer to either informed entrepreneurs or community members but instead build on the 'farmer multiple'.

Recent methodological contributions in Science and Technology Studies may offer a further guidance along these lines, including the suggestions to design such methods as activities of collective meaning making (Macnaghten 2020) and to take develop methods that better capture the variable real-life context of farmers (Almekinders et al. 2019). These methodological approaches elicit farmers voices by focusing on technologies as they are encountered in various real-life contexts, thereby allowing for different views (and different farmers) to emerge. Approaches, in other words, that can elicit farmers' voices in ways that incorporate rather than eliminate the 'farmer multiple'. Taking into account this diversity may provide a step forward in creating a well-informed and reasonable debate about the future of GM crops where the interests of the African farmer are put at front.

Finally, the diverging representations of the African farmer in GM crops we found may not be limited to cases analysed here. Similar fault lines in stakeholder representations may expected to arise in discussions over more recent emerging agricultural genetic technologies like ZFN, TALEN, and CRISPR-Cas9 (COGEM 2019). By identifying the main fault lines in the way different actors represent 
primary stakeholders, we open up space for ways to elicit the stakeholder's voice that can bring these diverging concerns into conversation.

Acknowledgements We would like to thank all members of the ERAfrica project 'Addressing societal challenges of biotechnology in Africa' for their valuable feedback on earlier drafts of this article.

Funding Research for this article was enabled by funding from the European Research Area Network Africa (ERAfrica), which forms part of the 7th Framework Programme of the European Union.

Open Access This article is licensed under a Creative Commons Attribution 4.0 International License, which permits use, sharing, adaptation, distribution and reproduction in any medium or format, as long as you give appropriate credit to the original author(s) and the source, provide a link to the Creative Commons licence, and indicate if changes were made. The images or other third party material in this article are included in the article's Creative Commons licence, unless indicated otherwise in a credit line to the material. If material is not included in the article's Creative Commons licence and your intended use is not permitted by statutory regulation or exceeds the permitted use, you will need to obtain permission directly from the copyright holder. To view a copy of this licence, visit http://creativecommons.org/licen ses/by/4.0/.

\section{References}

African Agricultural Technology Foundation (AATF). (2019). About us. https://www.aatf-africa.org/ about-us/who-we-are/. Accessed 6 January 2021.

African Centre for Biodiversity. (2020). Genome editing - the next GM techno fix doomed to fail. Johannesburg: ACB.

Almekinders, C. J. M., Beumer, K., Hauser, M., Misiko, M., Gatto, M., Nkurumwa, A. O., \& Erenstein, O. (2019). Understanding the relations between farmers' seed demand and Research methods: the challenge to do better. Outlook on Agriculture, 48, 16-21.

Ashton, G. (2012). Bill Gates' support of GM crops is wrong approach for Africa. Panmazuka News. https://www.pambazuka.org/governance/bill-gates-support-gm-crops-wrong-approach-africa. Accessed 6 January 2021.

Ayele, S. (2007). The legitimation of GMO governance in Africa. Science and Public Policy, 34, 239-249.

Badstue, L. B., Bellon, M. R., Berthaud, J., Ramírez, A., Flores, D., \& Juárez, X. (2007). The dynamics of farmers' maize seed supply practices in the Central Valleys of Oaxaca, Mexico. World Development, 35, 1579-1593.

Bate, R. (2002). Traders, farmers unite at summit protest. United Press International. http://www.upi. com/Business_News/Security-Industry/2002/08/28/Traders-farmers-unite-at-summit-protest/40601 030559412/. Accessed 6 January 2021.

Beckwith, J. A., Hadlock, T., \& Suffron, H. (2003). Public perceptions of plant biotechnology - a focus group study. New Genetics and Society, 22, 125-141.

Bennett, R., Buthelezi, T. J., Ismael, Y., \& Morse, S. (2003). Bt cotton, pesticides, labour and health. A case study of smallholder farmers in the Makhathini Flats, Republic of South Africa. Outlook on Agriculture, 32, 123-128.

Beumer, K. (2019). How to include socio-economic considerations in decision-making on agricultural biotechnology? Two models from Kenya and South Africa. Agriculture and Human Values, 36, 669-684.

Beyers, L., \& Thirtle, C. (2003). Can GM-technologies help African smallholders? The impact of Bt cotton in the Makhathini Flats of KwaZulu-Natal. Paper presented at the $25^{\text {th }}$ international conference of agricultural economists, August 16-22, 2003, Durban, South Africa.

Bijker, W. E., \& Law, J. (1992). Shaping technology/building society: Studies in socio-technical change. Cambridge, MA: MIT Press.

Biotechnology and GMO commission at the global forum at NASREC (2002). http://www.ukabc.org/ wssd_biotechandgmocommission.pdf. Accessed 24 May 2016. 
Biowatch (2002). The Johannesburg declaration on biopiracy, biodiversity and community rights. UK Agricultural Biodiversity Coalition. http://www.ukabc.org/johannesburgdeclaration.pdf. Accessed 6 January 2021.

Burton, R. J. F. (2004). Seeing through the 'good farmer's' eyes: towards developing an understanding of the social symbolic value of 'productivist' behaviour. Sociologia Ruralis, 44, 195-215.

Burton, R. J. F., \& Wilson, G. A. (2006). Injecting social psychology theory into conceptualisations of agricultural agency: towards a post-productivist farmer self-identity? Journal of Rural Studies, 22, 95-115.

Carpenter, J. E. (2010). Peer-reviewed survey indicate positive impact of commercialized GM crops. Nature Biotechnology, 28, 319-321.

CheThoener, V. (2019). The government must support agroecological agriculture. Here's why. https:// www.greenpeace.org/africa/en/publications/7554/the-government-must-support-eco-agro-heres -why/. Accessed 6 January 2021.

COGEM (2019) Gene Edited Crops; Global Perspectives and Regulation. Report of the COGEM International Symposium, 10 October 2019, The Netherlands Commission on Genetic Modification (COGEM).

Cohen-Cole, L. (2008). African farmers don't need Monsanto's biotechnology, they need self-determination. Organic Consumers Association. https://www.organicconsumers.org/news/african-farme rs-dont-need-monsantos-biotechnology-they-need-self-determination. Accessed 6 January 2021.

Doucleff, M. (2013). Will GMOs Help Protect Ugandan Families Against Hunger? The Salt. https:// www.npr.org/sections/thesalt/2013/06/17/192789454/will-gmos-help-protect-ugandan-familiesagainst-hunger?t=1568376788769. Accessed 6 January 2021.

Fischer, K. (2016). Why new crop technology is not scale-neutral - a critique of the expectations for a crop-based African Green Revolution. Research Policy, 45, 1185-1194.

Flowers, K. (2016). How biotech will help achieve zero hunger. Forbes opinion. http://www.forbe s.com/sites/gmoanswers/2016/01/12/zero-hunger-with-biotechnology/\#20d3f15d7759. Accessed 6 January 2021.

Food and Agriculture Organization of the United Nations (2004). The state of food and agriculture. Agricultural biotechnology: meeting the needs of the poor? Rome: FAO.

Food and Agriculture Organization of the United Nations (2015). The state of food and agriculture. Social protection and agriculture: breaking the cycle of rural poverty. Rome: FAO

Giddings, V. (2002). A turning point in Johannesburg? Nature Biotechnology, 20, 1081.

Gouse, M., Kirsten, J., \& Jenkins, L. (2003). Bt cotton in South Africa: Adoption and the impact on farm incomes amongst small-scale and large scale farmers. Agrekon, 42, 15-28.

Gouse, M., Kirsten, J., Shankar, B., \& Thirtle, C. (2005). Bt cotton in KwaZulu Natal: technological triumph but institutional failure. http://www.grain.org/system/old/research_files/Gouse_etal.pdf. Accessed 7 October 2016.

Gouse, M., Shankar, B., \& Thirtle, C. (2008). The decline of Bt cotton in KwaZulu-Natal: technology and institutions. In W. G. Mosely \& L. C. Gray (Eds.), Hanging by a thread: cotton, globalization and poverty in Africa (pp. 103-120). Athens, OH: Ohio University Press.

Gregory, P., Stewart, R. \& Stavrou, S. (2002). Adoption of Bt cotton by small-scale farmers in South Africa. Pesticide Outlook (February): 31-34.

Haggerty, J., Campbell, H., \& Morris, C. (2009). Keeping the stress off the sheep? Agricultural intensification, neoliberalism, and 'good' farming in New Zealand. Geoforum, 40, 767-777.

Hofs, J.-L., Fok, M., \& Vaissayre, M. (2006). Impact of Bt cotton adoption on pesticide use by smallholders: a 2-year survey in Makhatini Flats (South Africa). Crop Protection, 25, 944-988.

IRIN (n.k.). GM debate fought on cotton fields of KZN. IRIN News. http://www.irinnews.org/repor t/58064/south-africa-gm-debate-fought-cotton-fields-kzn. Accessed 6 January 2021.

Ismael, Y., Bennett, R., \& Morse, S. (2001). Farm level impact of Bt cotton in South Africa. Biotechnology and Development Monitor, 48, 15-19.

Ismael, Y., Bennett, R., \& Morse, S. (2002). Benefits from Bt cotton use by smallholders farmers in South Africa. AgBioForum, 5, 1-5.

Jansen, K., \& Gupta, A. (2009). Anticipating the future: 'biotechnology for the poor' as unrealized promise? Futures, 41, 436-445.

Jasanoff, S. (2005). Designs on nature: Science and democracy in Europe and the United States. Princeton: Princeton University Press.

Jasanoff, S. (2013). States of knowledge: The co-production of science and the social order. London: Routledge. 
Kearnes, M., Grove-White, R., Macnaghten, P., Wilsdon, J., \& Wynne, B. (2006). From bio to nano: learning lessons from the UK agricultural biotechnology controversy. Science as Culture, 15, 291-307.

Kirsten, J., \& Gouse, M. (2002). Bt cotton in South Africa: adoption and impact on farm incomes amongst small- and large-scale farmers. Information Systems for Biotechnology. http://www.isb. vt.edu/articles/oct0204.htm. Accessed 24 May 2016.

Kuyek, D. (2002). Genetically modified crops in African agriculture: implications for small farmers. GRAIN. https://www.grain.org/article/entries/8-genetically-modified-crops-in-african-agriculture-implicationsfor-small-farmers. Accessed 6 January 2021.

Latour, B. (1992). Where are the missing masses? The sociology of a few mundane artifacts. In W.E. Bijker, \& J. Law (Eds.), Shaping technology/building society, ed. (pp. 225-259). Cambridge, MA: MIT Press.

Latour, B. (2005). From Realpolitik to Dingpolitik - or how to make things public. In B. Latour \& P. Weibel (Eds.), Making things public: atmospheres of democracy (pp. 14-41). Cambridge, MA: MIT Press.

Levidow, L., \& Carr, S. (1996). Biotechnology risk regulation in Europe. Science and Public Policy, $23,134$.

Levidow, L., \& Carr, S. (2009). GM food on trial: testing European democracy. London: Routledge.

Levidow, L., Carr, S., \& Wield, D. (2005). European Union regulation of agri-biotechnology: precautionary links between science, expertise and policy. Science and Public Policy, 32, 261-276.

Lewis, C. P., Newell, J. M., Herron, C. M., \& Nawabu, H. (2010). Tanzanian farmers' knowledge and attitudes to GM biotechnology and the potential us of GM crops to provide improved levels of food security. A qualitative study. BMC Public Health, 10, 407.

Ma, X., Mau, M., \& Sharbel, T. F. (2018). Genome editing for global food security. Trends in Biotechnology, $36,123-127$.

Macnaghten, P. (2020). Towards an anticipatory public engagement methodology: deliberative experiments in the assembly of possible worlds using focus groups. Qualitative Research. https://doi. org/10.1177/1468794120919096.

Maina, A. et al. (2020). Genetically modified varieties should not be approved in Kenya. https://twitter.com/ KBiodiv/status/1278957480731709441/photo/1. Accessed 6 January 2021.

Matthews, J. (2002). The fake parade. Freezerbox Magazine. https://www.freezerbox.com/archive/print .php?id=254. Accessed 6 January 2021.

Matthews, J. (2003). Modifying protests: how the biotech industry is garnering support. The Ecologist. http:// www.theecologist.org/investigations/science_and_technology/268719/modifying_protests_how_the_ biotech_industry_is_garnering_support.html. Accessed 6 January 2021.

McGuire, J., Wright Morton, L., \& Cast, A. D. (2013). Reconstructing the 'good farmer' identity: shifts in farmer identities and farm management practices to improve water quality. Agriculture and Human Values, 30, 57-69.

McHenry, H. (1997). Wild flowers in the wrong fields are weeds! Examining farmers' constructions of conservation. Environment and Planning A, 30, 1039-1053.

Mitra, B, \& Okonski, K. (2002). Farmers from Africa and Asia march to demand freedom to farm. Liberty Institute. http://www.libertyindia.org/events/farmers_memorandum_wssd.htm. Accessed 24 May 2016.

Mittal, A., Rosset, P., Satheesh, P.V., Vint, R., \& Sorensen, N. (2002). Statement of solidarity with Southern African nations over GM food and crops. GM Watch. http://www.gmwatch.org/news/archi ve/2002/2955-southern-africa-and-gm-food-multiple-items-including-statement-of-solidarity. Accessed 6 January 2021.

Mol, A. (2003). The body multiple: Ontology in medical practice. Durham: Duke University Press.

Morse, S., \& Bennett, R. (2008). The impact of Bt cotton on farmer livelihoods in South Africa. http://epubs .surrey.ac.uk/351106/1/Impact\%20 of\%20Bt\%20cotton\%20on\%20farmer\%20livelihoods\%20in $\% 20$ Sou th\%20Africa\%20 \%20Int\%20Journal\%20of\%20Biotechnology.pdf. Accessed 6 January 2021.

Morse, S., \& Mannion, A. M. (2009). Can genetically modified cotton contribute to sustainable development in Africa? Progress in Development Studies, 9, 225-247.

Okonski, K. (2002). Farmers from Africa and Asia march to demand freedom to trade. Liberty Institute. http://www.libertyindia.org/events/farmers_march_wssd.htm. Accessed 24 May 2016.

Paarlberg, R. L. (2008). Starved for science. How biotechnology is being kept out of Africa. Cambridge: Harvard University Press.

Patel, R. (2012). Stuffed and starved. From farm to fork. The hidden battle for the world food system. New York: Melville House.

Randall, R. (2014). Are African farmers in danger of becoming slaves to patented seeds? https://geneticlit eracyproject.org/2014/12/15/are-african-farmers-in-danger-of-becoming-slaves-to-patented-seeds/. Accessed 6 January 2021. 
van Rijnsoever, F. J. (2017). (I can't get no) saturation: a simulation and guidelines for sample sizes in qualitative research. PLOS ONE, 12, e0181689.

Saugeres, L. (2002). The cultural representation of the farming landscape: masculinity, power and nature. Journal of Rural Studies, 18, 373-384.

Schneider, M. (2015). What, then, is a Chinese peasant? Nongmin discourses and agroindustrialization in contemporary China. Agriculture and Human Values, 32, 332-346.

Schnurr, M. A. (2012). Inventing Makhathini: Creating a prototype for the dissemination of genetically modified crops into Africa. Geoforum, 43, 784-792.

Schnurr, M. A., \& Mujabi-Mujuzi, S. (2014). "No one asks for a meal they’ve never eaten”. Or, do African farmers want genetically modified crops? Agriculture and Human Values, 31, 643-648.

Scoones, I. (2008). Mobilizing against GM crops in India, South Africa and Brazil. Journal of Agrarian Change, 8, 315-344.

Setten, G. (2004). The habitus, the rule and the moral landscape. Cultural Geographies, 11, 389-415.

Shankar, B., \& Thirtle, C. (2005). Pesticide productivity and transgenic cotton technology: the South African smallholder case. Journal of Agricultural Economics, 56, 97-115.

Shikwati, J. (2002). I do not need white NGOs to speak for me. The Times. https://www.globalpolicy.org/ component/content/article/176/31379.html. Accessed 6 January 2021.

Shucksmith, M., \& Herrmann, V. (2002). Future changes in British agriculture: projecting divergent farm household behaviour. Journal of Agricultural Economics, 53, 37-50.

Silvasti, T. (2003). The cultural model of "the 'good farmer"' and the environmental question in Finland. Agriculture and Human Values, 20, 143-150.

Smale, M., Zambrano, P., Falck-Zepeda, J., \& Gruère, G. (2006). Parables: applied economics literature about the impact of genetically engineered crop varieties in developing economies. IFPRI-EPT discussion paper 158. https://core.ac.uk/download/pdf/6288910.pdf. Accessed 6 January 2021.

Small-Scale Farmers Convergence (2002). Press statement by smallholder farmers and fish harvesters. UK Agricultural Biodiversity Coalition. http://www.ukabc.org/wssd_farmers.pdf. Accessed 6 January 2021.

Soini, K., \& Aakkula, J. (2007). Framing the biodiversity of agricultural landscape: the essence of local conceptions and constructions. Land Use Policy, 24, 311-321.

Soleri, D., et al. (2008). Testing assumptions underlying economic research on transgenic food crops for Third World farmers: evidence from Cuba, Guatemala and Mexico. Ecological Economics, 67, 667-682.

Soleri, D., \& Cleveland, D. A. (2001). Farmers' genetic perceptions regarding their crop populations: an example with maize in the central valley of Oaxaca, Mexico. Economic Botany, 55, 106-128.

Star, S. L., \& Griesemer, J. R. (1989). Institutional ecology, 'translations' and boundary objects: amateurs and professionals in Berkeley's museum of vertebrate zoology, 1907-39. Social Studies of Science, 19, $387-420$.

Thomson, J. (2000). Developing countries can't wait and see. Harvard Kennedy School Center for International Development. http://www.agbioworld.org/newsletter_wm/index.php?caseid=archiveandnewsi $\mathrm{d}=803$. Accessed 24 May 2016.

Toenniessen, G. H. (1995). Plant biotechnology and developing countries. Trends in Biotechnology, 13, 404-409.

Townsend, R. (2015). Ending poverty and hunger by 2030: an agenda for the global food system. Washington D.C.: World Bank.

United Press International. Heated debate over GM food at summit. AgBioView. http://www.agbioworld.org/ newsletter_wm/index.php?caseid=archiveandnewsid=1500. Accessed 24 May 2016.

Williams, R., Pelser, D., \& Black, V. (2014). Agroecology is best practice. Biowatch South Africa's work with smallholder farmers. Durban: Biowatch South Africa.

Witt, H., Patel, R., \& Schnurr, M. (2006). Can the poor help GM crops? Technology, representation and cotton in the Makhathini Flats, South Africa. Review of African Political Economy, 33, 497-513.

Woodward, B., Brink, J., \& Berger, D. (1999). Can agricultural biotechnology make a difference in Africa? AgBioForum, 2, 175-181.

Wynne, B. (2001). Creating public alienation: expert cultures of risk and ethics on GMOs. Science as Culture, 10, 445-481.

Heong, Y.C. (2006). The truth behind GM cotton in the Makhathini flats. GM Watch. http://gmwatch.org/ news/archive/2006/5358-the-truth-behind-gm-cotton-in-the-makhathini-flats-18102006. Accessed 6 January 2021.

Zaidi, S. S., et al. (2019). New plant breeding technologies for food security. Science, 353, 1390-1391. 
Zerbe, N. (2004). Feeding the famine? American food aid and the GMO debate in Southern Africa. Food Policy, 29, 593-608.

Publisher's Note Springer Nature remains neutral with regard to jurisdictional claims in published maps and institutional affiliations. 